\title{
ESSAY
}

\section{THEORIZING YES: AN ESSAY ON FEMINISM, LAW, AND DESIRE}

\begin{abstract}
Katherine M. Franke*
In this Essay, Professor Franke observes that, unlike feminists from other disciplines, feminist legal theorists have neglected to formulate a positive theory of female sexuality. Instead, discussions of female sexuality have been framed as either a matter of dependency or danger. Professor Franke begins her challenge to this scheme by asking why legal feminism has accepted unquestionably the fact that most women reproduce in their lifetimes. Why have not social forces that incentivize motherhood-a dynamic she terms repronormativity-been exposed to as exacting a feminist critique as have heteronormative forces that normalize heterosexuality? Furthermore, she continues by noting that when feminist legal theory renders sex as dangerous, such analysis risks advancing the view that the only acceptable answer to any sexual proposition is "no." Professor Franke cautions that the willingness of most legal feminists to maternalize uncritically the female subject or to conceptualize sex as the inevitable site of danger for women, effectively marginalizes, if not erases, the possibility of non-reproductive female sexual desire and pleasure.
\end{abstract}

Legal feminism is by no means a discipline autonomous from a larger set of conversations self-identified as feminist in nature. Indeed, we, the legal feminists, regard ourselves as concerned with issues that are central to a broader intellectual and political feminist movement: sexbased equality in the workplace, reproductive rights, domestic violence, the needs of working mothers, sexual harassment, and rape, to name only a few such issues, figure centrally in feminist theory-legal and otherwise. Yet, there appears to be an increasing disconnect between legal feminism and other feminist disciplines when it comes to the scope and meaning of a feminist approach to sexuality, desire, and women's "hedonic lives," to borrow a term Robin West introduced into the legal literature some years ago. ${ }^{1}$ Without a doubt, when it comes to sex, we have done a more than adequate job of theorizing the right to say no, but we have left to others the task of understanding what it might mean to say yes. However, as Carole Vance has reminded us for over twenty years, a feminist approach to sexual matters must "simultaneously . . . reduce the dangers women

* Professor of Law, Columbia University. My thanks to Wendy Brown, Alexandra Chasin, Lisa Duggan, Martha Ertman, Renée Römkens, Carol Rose, Carol Sanger, and Carole Vance for their thoughtful comments on earlier versions of this Essay. Particular thanks to Kari Hong for her excellent editorial assistance with this Essay.

1. Robin L. West, The Difference in Women's Hedonic Lives: A Phenomenological Critique of Feminist Legal Theory, 3 Wis. Women's L.J. 81, 81 (1987). 
face and ... expand the possibilities, opportunities, and permissions for pleasure that are open to them." 2

In this Essay I will ask a set of questions intended to highlight the degree to which legal feminism has, by and large, reduced questions of sexuality to two principal concerns for women: dependency, and the responsibilities that motherhood entails, and danger, such as sexual harassment, rape, incest, and domestic violence. ${ }^{3}$ This concentration on the elimination of sexual danger and dependency for women risks making "women's actual experience with pleasure invisible, overstat[ing] danger until it monopolizes the entire frame, positions women solely as victims, and fails to empower our movement with women's curiosity, desire, adventure and success." 4 Curiously, since the end of the so-called "sex wars" 5 in the 1980 s, it seems that legal feminists have ceded to queer theorists the job of imagining the female body as a site of pleasure, intimacy, and erotic possibility.

While we devote our considerable energies to addressing sexuality understood in terms of freedom from oppressive practices, feminists in other disciplines continue to simultaneously approach questions of sexuality in both negative (freedom from) and positive (freedom to) terms. ${ }^{6}$ Why do legal feminists frame questions of sexuality more narrowly than our colleagues in other fields? Is there something intrinsic to a legal approach to sexuality that deprives us of the tools, authority, or expertise to

2. Carole S. Vance, More Danger, More Pleasure: A Decade After the Barnard Sexuality Conference, 38 N.Y.L. Sch. L. Rev. 289, 290 (1993).

3. In their Foreword to a symposium on the Gender, Work \& Family Project's Inaugural Feminist Legal Theory Lecture given by Martha Fineman, Project Co-Directors Adrienne Davis and Joan Williams identified the "eroticization of dominance" understood as "the sex/violence axis of gender formation," and "conflict that people experience as they negotiate between their work lives and their family lives," as the two principal strands of contemporary feminist legal theory. Adrienne D. Davis \& Joan C. Williams, Foreword, 8 Am. U. J. Gender Soc. Pol'y \& L. 1, 2-3 (2000).

4. Vance, supra note 2, at 290.

5. See, e.g., Caught Looking: Feminism, Pornography and Censorship 4-8 (Kate Ellis et al. eds., 1992); Lisa Duggan \& Nan D. Hunter, Sex Wars: Sexual Dissent and Political Culture 1, 30-78 (1995); Alice Echols, Daring To Be Bad: Radical Feminism in America 1967-1975, at 289-91 (1989); Lisa Duggan, The Sex Panic: Women, Censorship, and "Pornography": An Historical Overview, 38 N.Y.L. Sch. L. Rev. 25, 28 (1993); Vance, supra note 2 , at 289 .

6. To name only a few, from Cinema Studies, see, e.g., Laura Kipnis, Bound and Gagged: Pornography and the Politics of Fantasy in America, at x-xi (1996); Laura Kipnis, Ecstasy Unlimited: On Sex, Capital, Gender, and Aesthetics 8-11 (1993); Laura Kipnis, Adultery, 24 Critical Inquiry 289, 293 (1998); from Anthropology, see, e.g., Micaela di Leonardo, Exotics at Home: Anthropologies, Others, American Modernity 326-46 (1998); The Gender/Sexuality Reader: Culture, History, Political Economy 5-8 (Micaela di Leonardo ed., 1997); Deborah A. Elliston, Erotic Anthropology: "Ritualized Homosexuality" in Melanesia and Beyond, 22 Am. Ethnologist 848, 855-56 (1995); from History, see, e.g., Judith R. Walkowitz, City of Dreadful Delight: Narratives of Sexual Danger in Late-Victorian London 113-22 (1992); from American Studies, see, e.g., Lauren Berlant, The Queen of America Goes to Washington City: Essays on Sex and Citizenship 5 (1997). See generally Special Issue on Intimacy, 24 Critical Inquiry (1998). 
address desire head on? Can law protect pleasure? Should it? Or have legal feminists implicitly made the (I believe mistaken) strategic judgement that feminist legal theory cannot explore sexuality positively until danger and dependency are first eliminated?

I cannot promise answers to these difficult questions for law and for feminism. Rather, with this Essay I hope to stimulate a conversation among legal feminists about our approaches to sexuality, and by asking some uncomfortable questions, foreground what I believe are unexamined premises in legal feminist approaches to dependency and danger that could bear more critical attention.

In the discussion that follows, I first examine the two principal manners in which legal feminists tend to approach questions of sexuality: dependency and danger. I then situate these approaches within a larger feminist context in which I consider viable future directions for feminist legal theory in light of the complex interrelationships of sexuality, gender, and desire.

\section{The Repronormativity of Motherhood}

Motherhood and its implications figure centrally in virtually all feminist agendas. However, for much of first and second wave legal feminism, issues of gender collapse quite quickly into the normative significance of our roles as mothers. Grounding feminist legal theory in object relations theory ${ }^{7}$ and demanding that women's participation in the wage labor market be compatible with our responsibilities as mothers ${ }^{8}$ are only two salient examples of how the legal feminist frame tends to collapse women's identity into motherhood. The centrality, presumption, and inevitability of our responsibility for children remain a starting point for many, if not most, legal feminists. ${ }^{9}$

Consider two propositions: The overwhelming majority of women are heterosexual. The overwhelming majority of women are mothers. The degree to which social preferences and prohibitions-otherwise known as compulsory heterosexuality-contribute to the "fact" stated by the first proposition has become relatively accepted within feminist, and certainly queer, theory circles. Feminists have become, to varying degrees, sensitive to the technologies of power that steer, suggest, coerce, and demand that women be heterosexual and that abjection lies in the refusal of such a demand.

7. See, e.g., Nancy Chodorow, The Reproduction of Mothering: Psychoanalysis and the Sociology of Gender 11 (1978); Robin West, Jurisprudence and Gender, 55 U. Chi. L. Rev. 1, 1 (1988).

8. See, e.g., Joan Williams, Unbending Gender: Why Family and Work Conflict and What To Do About It, at x (2000).

9. Id. See also Sara Ruddick, Thinking Mothers/Conceiving Birth, in Representations of Motherhood 29, 36 (Donna Bassin et al. eds., 1994) ("To respect female bodies means respecting, even treasuring, the birthgiving vulnerabilities and procreative powers of females."). 
Yet the same cannot be said of the second proposition laid out above: Most women are mothers. Why is it that we are willing to acknowledge that heteronormative cultural preferences play a significant role in sexual orientation and selection of sexual partners, while at the same time refusing to treat repronormative forces as warranting similar theoretical attention? ${ }^{10}$ If you believe the statistics, women are more likely not to have borne a child in their lifetimes ${ }^{11}$ than to be lesbian. ${ }^{12}$ Is there any principled reason why legal feminists might not want to devote some attention to exposing the complex ways in which reproduction is incentivized and subsidized in ways that may bear upon the life choices women face? To ask such a question is to risk being labeled unfeminist. ${ }^{13}$ To

10. To be fair, Dorothy Roberts and Carol Sanger are two legal theorists who have raised this issue in their work. Roberts has noted the contrast between coercive natalism for white women and the forces that discourage Black women from procreating. See, e.g., Dorothy E. Roberts, The Genetic Tie, 62 U. Chi. L. Rev. 209, 239 \& nn.118-19 (1995); Dorothy E. Roberts, Racism and Patriarchy in the Meaning of Motherhood, 1 Am. U. J. Gender Soc. Pol'y \& L. 1, 10-11 (1993); Joan C. Callahan \& Dorothy E. Roberts, A Feminist Social Justice Approach to Reproduction-Assisting Technologies: A Case Study on the Limits of Liberal Theory, 84 Ky. L.J. 1197, 1225 (1995-1996). Sanger has applied a similar analysis to other presumptively disfavored mothers. See, e.g., Carol Sanger, M is for the Many Things, 1 S. Cal. Rev. L. \& Women's Stud. 15, 49-51 (1992) [hereinafter Sanger, $\mathrm{M}$ is for the Many Things]; Carol Sanger, Separating from Children, 96 Colum. L. Rev. 375, 410 (1996); see also Julia E. Hanigsberg, Homologizing Pregnancy and Motherhood: A Consideration of Abortion, 94 Mich. L. Rev. 371, 417-18 (1995) (calling for "reconceptualizing the abortion decision within the context of mothering decisions").

11. Census data reveals that $19 \%$ of women will not have borne a child by their fortyfourth birthday. Amara Bachu \& Martin O'Connell, U.S. Dep't of Commerce, Current Population Reports: Fertility of American Women: June 19982 tbl. A (2000). Of course, women who have not borne children themselves can be and are mothers, whether through adoption, parenting of their partner's children, or what Patricia Hill Collins calls "othermothering." Patricia Hill Collins, Black Feminist Thought: Knowledge, Consciousness, and the Politics of Empowerment 119 (1990).

12. Of course, the validity of statistics regarding the prevalence of lesbians in the population is vulnerable on a number of fronts: underreporting by lesbians due to homophobia, difficulty defining the category "lesbian," and the important distinction between lesbian acts and lesbian identity are among the most prominent. Reports of the incidence of lesbianism in the U.S. population vary from Kinsey's figure that $13 \%$ of women had reported reaching orgasm with another woman at some point in their lives, to the National Opinion Research Center's 1992 report entitled "The Social Organization of Sexuality" that found only $1.3 \%$ of women had engaged in "homosexual" activity in the preceding year. See Alfred C. Kinsey et al., Sexual Behavior in the Human Female 454 (1953); Edward O. Laumann et al., The Social Organization of Sexuality: Sexual Practices in the United States 294 (1994). Naomi Mezey has done a nice job of surveying and critiquing this literature. Naomi Mezey, Dismantling the Wall: Bisexuality and the Possibilities of Sexual Identity Classification Based on Acts, 10 Berkeley Women's L.J. 98, 104-06 (1995).

13. There is a burgeoning academic and popular literature that raises the question of "childless by choice." See, e.g., Jane Bartlett, Will You Be Mother?: Women Who Choose to Say No, at ix (1994); Joan Brady, I Don't Need a Baby To Be Who I Am: Thoughts and Affirmations on a Fulfilling Life, at xi-xvi, 112-25 (1998); Elinor Burkett, The Baby Boon: How Family-Friendly America Cheats the Childless 7 (2000); Mardy S. Ireland, Reconceiving Women: Separating Motherhood from Female Identity, at vii (1993); 
suggest that we reconceptualize procreation as a cultural preference rather than a biological imperative, and then explore ways in which to lessen or at least modify the demand to conform to that preference, is to initiate a conversation within feminism that has been explicitly and curtly rejected by some legal feminists. However, it is a conversation that necessarily demands feminist discussants, for only by positing the possibility of female identity divorced from mothering can we make mothering ethically and politically intelligible. Surely mothering grounds the lives of many women, but that ground, once taken for granted, risks obscuring the figure of woman, whose identity extends beyond her role as mother.

Notwithstanding the prevalence of both childlessness and lesbianism, ${ }^{14}$ somehow reproduction continues to be regarded as more inevitable and natural than heterosexuality. That is to say, repronormativity remains in the closet even while heteronormativity has stepped more into the light of the theoretical and political day. Reproduction has been so taken for granted that only women who are not parents are regarded as having made a choice-a choice that is constructed as nontraditional, nonconventional, and for some, non-natural. ${ }^{15}$ In a telling switch, the

Carolyn M. Morell, Unwomanly Conduct: The Challenges Of Intentional Childlessness, at xiii (1994); Martha E. Gimenez, Feminism, Pronatalism, and Motherhood, in Mothering: Essays in Feminist Theory 287, 299-301 (Joyce Trebilcot ed., 1983); Irene Reti, Introduction to Childless by Choice: A Feminist Anthology 1-3 (Irene Reti ed., 1992); Lisa Belkin, Your Kids are Their Problem, N.Y. Times, July 23, 2000, (Magazine), at 30; Enid Nemy, No Children. No Apologies., N.Y. Times, Apr. 6, 1995, at C12. By listing these publications here, I do not mean to endorse the arguments that their authors have made. In fact, some of these texts I would characterize as proto-, neo-, or anti-feminist in their approaches, just as I would characterize the work of Naomi Wolf and Katie Roiphe. Burkett, for instance, raises some interesting concerns for the lay reader regarding the degree to which parenting is subsidized for middle-class families in public and private ways, but she does so, seemingly, in complete ignorance of the real burdens and discriminations that working mothers suffer at home and at work-such as the history and current reality of losing their jobs when they get pregnant, or losing promotions for sexist reasons. See Burkett, supra, at 25-61 (describing how workers with children gain substantial benefits in the workplace). I mention these publications to illustrate what appears to be something of a growing sentiment among childless workers that their life choices are treated as of secondary importance when compared with those workers engaged in child-rearing.

14. By setting up the comparison this way, I do not mean to reify the notion that lesbians do not have children. Of course we do, and in greater numbers each year. Rather my goal is to expose the degree to which even thoughtful legal feminists persist in the idea that reproduction is the result of a natural drive not worthy of our critical attention except when socially discouraged, while sexual orientation is, at least in theory, understood to be subject to powerful cultural influences.

15. The construction of the woman who chooses not to have children is contrasted with the woman who desires to, but is unable to bear children. The tragedy of her predicament reinforces the marginality of the woman who is childless by choice. Interestingly enough, in a context in which nature has visited a cruel deprivation on the "barren woman," the woman who chooses not to reproduce is positioned as having made a choice that violates some natural instinct, order, or destiny. See Callahan \& Roberts, supra note 10, at 1225 ("Our society does not think it is just fine for people to remain single and childless deliberately or for married people to remain childless deliberately. Infertility is constructed as a nearly unbearable tragedy; deliberate childlessness is constructed as nearly 
issue of choice flips for lesbians, who are constructed as choosing motherhood, given that lesbians continue to have an identity understood as nonreproductive in nature. Similarly, the official story of reproduction as a natural drive is deeply racialized, as women of color have struggled against social forces that have at times coercively appropriated, and at other times coercively discouraged their reproduction in numerous ways. So too, in recent debates over welfare reform, poor mothers have been vilified for having borne children strategically. ${ }^{16}$ While a claim not borne out by any reliable studies, it has justified the punishment of women who reproduce for the wrong reasons. ${ }^{17}$

Thus, reproduction raises numerous sticky normative questions, yet underexplored within feminism, with respect to choice, coercion, and policies that incentivize and disincentivize reproductive uses of women's sexual bodies-not only for women who occupy law's margins, such as lesbians and women of color, but also for women whose reproduction we regard as unproblematic.

The first objection one hears when one questions the normativity of reproduction is: "But we must reproduce the species."18 Certainly this must be right, but the conversation-stopping power of this natalist objection should not be overstated. ${ }^{19}$ The fact that the future of the species depends upon ongoing reproduction ${ }^{20}$ does not relieve us from devoting critical attention to the manners in which this biological demand becomes culturally organized. Feminists have undertaken deep and nuanced critiques of the social and sexual division of labor that devalues

unimaginable selfishness.”). This flipping, of structuring the natural as the cultural and the cultural as the natural, merely illustrates the degree to which nature (here, infertility) has proven easier to transform than culture (the expectations that women be mothers).

16. Recent welfare reform has portrayed poor women as choosing to reproduce in order to receive larger welfare grants. See, e.g., Mimi Abramovitz, Under Attack, Fighting Back: Women and Welfare in the United States 35 (1996); Laura M. Friedman, Comment, Family Cap and the Unconstitutional Conditions Doctrine: Scrutinizing a Welfare Woman's Right to Bear Children, 56 Ohio St. L.J. 637, 657-59 (1995) (discussing various states' "Family Cap" programs); see also Personal Responsibility and Work Opportunity Reconciliation Act of 1996, 42 U.S.C. § 602 (a)(7)(A)(iii) (Supp. III 1997) (allowing waivers of federal welfare requirements for, inter alia, states that adopt family caps); C.K. v. N.J. Dep't of Health \& Human Servs., 92 F.3d 171, 194-95 (3d Cir. 1996) (upholding New Jersey Family Cap against constitutional and statutory challenge).

17. See Linda C. McClain, "Irresponsible" Reproduction, 47 Hastings L.J. 339, 352-58 (1996) (analyzing the various manners in which poor women's reproduction is figured as irresponsible).

18. So responded a prominent feminist philosopher of the family when I raised concerns about compulsory reproduction at a recent conference.

19. For an interesting discussion of the biological roots of mothering, see generally Sarah Blaffer Hrdy, Mother Nature: A History of Mothers, Infants, and Natural Selection 146-74 (1999).

20. Issues of world overpopulation and the disproportionate amount of world resources consumed by Americans make the "we have to reproduce the species" retort a more complex issue than a mere biological demand. See, e.g., Mona L. Hymel, The Population Crisis: The Stork, the Plow, and the IRS, 77 N.C. L. Rev. 13, 102-03 (1998). 
reproduction, largely assigns it to women in isolated households, and then refuses to remunerate it. ${ }^{21}$ Our response to this oppressive sexual history must go beyond the mere revaluation of women's reproductive labor such that the maternalization of female identity remains intact. ${ }^{22}$

The push to commodify dependency work has been an important means by which the separate spheres doctrine has been repudiated, but what has it done for women's sexuality generally? Surely our best strategy cannot lie in creative efforts to commodify the domain of sexuality that is the surplus above mere procreation, for it may be that its greatest value lies precisely in its excess. What might "acts that are not civic acts, like sex, [have to do with feminist] citizenship"?23 Or, as Jennifer Brown recently put it, what are we to make of activities like prayer and orgasm for which their market value bears little relevance to the value we derive from them?24 That is not to say that these activities are of no consumptive or productive value, but rather that we may prize them for the manner in which they figure outside of traditional valuations of exchange. "Revolution must involve heterogeneous expression, wasteful gift exchange (pure expenditure rather than accumulation, final consumption rather than productive consumption), and nonprocreative sex." 25

Martha Fineman's work is among the most sophisticated attempts to reconceptualize the practice of motherhood tout court. ${ }^{26}$ She has observed that " $[\mathrm{m}]$ otherhood [is] a colonized concept-an event physically practiced and experienced by women, but occupied and defined, given

21. E.g., Nancy C.M. Hartsock, Money, Sex, and Power 234-40 (1983); Carole Pateman, The Sexual Contract 116-53 (1988); Mary Jo Frug, Securing Job Equality for Women: Labor Market Hostility to Working Mothers, 59 B.U. L. Rev. 55, 59 (1979).

22. See Katharine T. Bartlett, Feminist Legal Methods, 103 Harv. L. Rev. 829, 830-31 (1990); Judith Resnik, On the Bias: Feminist Reconsiderations of the Aspirations for Our Judges, 61 S. Cal. L. Rev. 1877, 1906-28 (1988). For a critical account of the literature, see Vicki Schultz, Life's Work, 100 Colum. L. Rev. 1881, 1899-1907 (2000).

23. Berlant, supra note 6 , at 5 .

24. Brown writes:

[I]f we want to talk about what human beings are like, we face the limitations of any view that divides the world into production and consumption, with no third way. I think that (probably some, not all) human beings want and even need some time ... in which they neither produce nor consume, but merely (to put it in sort of new agey terms) "be," ... [such as] prayer, meditation, washing dishes (even when an electric dishwasher in the house could do the job), playing, sex, orgasm. It may be that each of these activities also has productive or consumptive properties, but I think that those properties are of secondary importance much of the time.

E-mail from Jennifer Gerarda Brown, Professor, Quinnipiac College School of Law, to Katherine Franke, Professor of Law, Columbia University (June 29, 2000, 11:33:59 CST) (on file with author).

25. Miranda Joseph, The Performance of Production and Consumption, 54 Soc. Text 25, 51 (1998).

26. E.g., Martha Albertson Fineman, The Neutered Mother, The Sexual Family, and Other Twentieth Century Tragedies (1995) [hereinafter Fineman, Neutered Mother]. 
content and value, by the core concepts of patriarchal ideology." 27 She urges us to sever our erotic relationships from our kinship relationships, pointing out that there is no necessary connection between the erotic bonds that tie adults to one another and the kinship ties that lash parent to child. Fineman's most recent work makes the claim that caring for children is society-preserving work that "produces and reproduces society," 28 and which must be done "if a society is to survive and perpetuate itself." ${ }^{29}$ These arguments are developed to justify a claim that mothers are owed a social debt for performing this work. ${ }^{30}$ Yet at times she too succumbs to an insufficiently critical reliance upon natalism. The altruistic needs of those who perform this all-important society-preserving work are, for Fineman, to be distinguished from other selfish lifestyle choices a person might make and for which they might seek public subsidies—such as purchasing an expensive sports car. ${ }^{31}$ Mothering, for Fineman, is social production worthy of substantial public support, while owning a Porsche is simple consumption, and therefore merely individual rather than society-preserving in nature. ${ }^{32}$

The normative distinction that sets up the altruism of mothers against the selfishness of Porsche drivers suffers from several weaknesses, not the least of which are the confusion between the social effect of a practice and an individual's motivation for engaging in the practice, ${ }^{33}$ and an impoverished account of the meanings of and relationships between social production, social reproduction, and consumption.

Beginning with Marx, various social theorists have worked hard to displace oppositions between production and consumption, the eco-

27. Martha A. Fineman, Images of Mothers in Poverty Discourses, 1991 Duke L.J. 274, 289-90.

28. Martha Albertson Fineman, Cracking the Foundational Myths: Independence, Autonomy, and Self-Sufficiency, 8 Am. U. J. Gender Soc. Pol'y \& L. 13, 19 (2000).

29. Id. at 18.

30. Id. at $16-19$.

31. See id. at 21 n.15. Fineman notes:

In particular, I have been struck by two quasi-economic responses to the point that caretakers should be compensated. I refer to one as the "Porsche Preference." This argument states that if someone prefers a child, this preference should not be treated differently than any other choice (like the choice to own a Porsche). Society should not subsidize either preference. I hope the societypreserving nature of children helps to distinguish that preference from the whim Id. of the auto fan.

32. The framing of the costs of mothering as a privileged form of cultural work, and as labor that must figure at the center of any feminist project, risks a built-in erasure of, if not disfavor for, other types of "society-preserving work" that are not repronormative in nature. Lauren Berlant shares a similar concern with respect to the connection between production and reproduction for women: "At this time in America, however, the reproducing woman is no longer cast as a potentially productive citizen, except insofar as she procreates: her capacity for other kinds of creative agency has become an obstacle to national reproduction." Berlant, supra note 6, at 100 .

33. I must thank Renée Römkens for bringing this distinction to my attention. 
nomic and the social, the individual and the collective. ${ }^{34}$ While Fineman, and many others, ${ }^{35}$ are correct that society reproduces itself through the process of biological reproduction, this is by no means the only manner in which social reproduction takes place, nor is it necessarily the most important. The reproduction of society takes place constantly through countless reiterative practices, many of which are structured as simultaneously productive and consumptive in nature. ${ }^{36}$ After all, this was the principal strategy of Henry Ford: "What was special about Ford . . . was his vision, his explicit recognition that mass production meant mass consumption . . . ." ${ }^{37}$ Thus, "production produces not only workers but Americans, loyal and proud General Motors employees [for instance], women, and gays and lesbians," 38 all of whom, as an essential part of their identity as Americans, are expected to, and do, consume at least in equal measure to that which they produce. Consumptive acts and behavior are thus at once deeply constitutive and productive in nature. One gains social status from using a gold card, carrying shopping bags from exclusive stores, and wearing brand names on the outside of your clothing. In latemodern American society, a minority social group can claim that it has achieved a level of social visibility, acceptance, and presence when it is recognized as a niche market. The gay community, for instance, celebrated the fact that alcohol manufacturers, such as SKYY Vodka, began to target the community in their marketing strategies. ${ }^{39}$ Martina Navratilova has been used by MasterCard in its advertisements to sell credit cards to lesbians and gays under the notion that we are building commu-

34. Miranda Joseph does a nice job of elaborating the intellectual histories that have undermined these binaries. See Joseph, supra note 25, at 25.

35. This view is not, of course, unique to Fineman. John Rawls has similarly framed both the family and the social utility of reproduction:

The family is part of the basic structure, since one of its main roles is to be the basis of the orderly production and reproduction of society and its culture from one generation to the next. ... [R] eproductive labor is socially necessary labor. Accepting this, a central role of the family is to arrange in a reasonable and effective way the raising of and caring for children, ensuring their moral development and education into the wider culture. . . . The family must ensure the nurturing and development of such citizens in appropriate numbers to maintain an enduring society.

These requirements limit all arrangements of the basic structure, including efforts to achieve equality of opportunity. The family imposes constraints on ways in which this goal can be achieved, and the principles of justice are stated to try to take these constraints into account.

John Rawls, The Idea of Public Reason Revisited, 64 U. Chi. L. Rev. 765, 788 (1997) (citation omitted).

36. "Not only is the individual's identity formed/expressed in production but the collectivity, social relations, are also determined through the mode of production." Joseph, supra note 25, at 29 (discussing Karl Marx's essay, The German Ideology).

37. David Harvey, The Condition of Postmodernity: An Enquiry into the Origins of Cultural Change 125-26 (1990).

38. Joseph, supra note 25, at 26.

39. Alexandra Chasin, Selling Out: The Gay and Lesbian Movement Goes to Market 134-41 (2000). 
nity by making purchases with a rainbow credit card: "The Rainbow card ... promotes the idea that personal consumption is an effective mode of political participation . ..." 40 Similarly, African Americans are urged to build the Black community by buying Black. ${ }^{41}$ Such examples illustrate how consumption "become[s] the site and structure through which the community enacts [and produces] its very existence." 42

Returning to Fineman's Porsche owner, if there is anything we have learned as members of modern political economies, it is that consumption is society-preserving work. On the other hand, while surely there is social value to the reproduction of the species, I question whether "society-preserving work" accurately or adequately describes how women actually experience the labor they are performing by having and raising children. "Women have children because they love them or the idea of them, to keep a marriage together, to meet social, spousal or parental expectations, to experience pregnancy, or to pass on the family name, genes, or silver." Professor Sanger continues, "[s] ometimes children are conceived for the benefit of existing children: to keep someone from being an only child," 43 or to provide bone marrow to a dying sibling. ${ }^{44}$ Indeed, I suspect that if polled, mothers would rank a species-regarding reason well behind more private and personal motivations for their decisions to reproduce. ${ }^{45}$ A recent letter to the editor of the New Yorker noted that "many adoptive families I know were driven not by an altruistic urge but by a selfish desire to create a family." 46 To portray mothering as purely altruistic, other-regarding, and socially valuable, and sports car

40. Id. at 198-99.

41. See Timothy Bates, Banking on Black Enterprise: The Potential of Emerging Firms for Revitalizing Urban Economies 31-72 (1993); Jeremiah Cotton, Towards a Theory and Strategy for Black Economic Development, in Race, Politics, and Economic Development 11, 29-30 (James Jennings ed., 1992); Lateef Mtima, African-American Economic Empowerment Strategies for the New Millennium-Revisiting the WashingtonDu Bois Dialectic, 43 How. L.J. 391, 429 (1999) ("African-Americans must restructure intracommunity attitudes to black enterprise. African-Americans must not merely 'buy black,' but must also step up the effort to establish and support more black entrepreneurial and professional endeavors."); Michael L. Moss, Harlem's Economic Paradox, N.Y. Times, Dec. 13, 1995, at A23 (discussing "buy black" sentiments at the root of fatal fire and commercial landlord dispute on Harlem's 125th Street shopping strip); cf. Chasin, supra note 39, at 50-53 (analogizing "Buy Black" to "Buy Queer").

42. Joseph, supra note 25 , at 44 .

43. Sanger, $\mathrm{M}$ is for the Many Things, supra note 10 , at 48 .

44. See id. at 48-49 (citing Denise Hamilton, Woman Is Having Baby to Save Her Ailing Daughter, L.A. Times, Feb. 16, 1990, at A1); Denise Grady, Son Conceived to Provide Blood Cells for Daughter, N.Y. Times, Oct. 4, 2000, at A24; Abigail Trafford, Brave New Reasons for Mothering: Having a Baby to Produce a Potential Organ Donor, Wash. Post, Feb. 27, 1990, at Z6.

45. "[P] oor people have children for the same reasons that other people have children. All the data shows that people have children because they want companionship or because children are valued in society." Martha Davis, Contemporary Challenges to Gender Equality, 43 N.Y.L. Sch. L. Rev. 159, 171 (1999).

46. Barbara C. Boches, Letter, New Yorker, Aug. 14, 2000, at 5. 
ownership as purely selfish and socially inconsequential, is to ignore the complex interrelations between production, reproduction, and consumption, ${ }^{47}$ as well as the social forces that govern the "choices" and priorities we set in our own lives. ${ }^{48}$

What is more, even though there is an enormous public interest in the labor performed by mothers-to the point that some feminist theorists describe children as a public good ${ }^{49}$ - children remain the private property of their parents, which is an arrangement most feminists do not find troubling. ${ }^{50}$ The politics of public value, public subsidy, but private accountability with respect to raising children is revealed to be quite paradoxical under close examination. A recent cover story in the New York Times Magazine profiled a family in the leadership of the home-schooling movement. A large number of home schoolers are fundamentalist christian families who, according to the New York Times Magazine, "are no longer fighting against the mainstream-they're 'dropping out' and creating their own private America." 51 Many families, like the Scheibners profiled in this article, are heeding the call of Paul Weyrich, a founder of the Christian Right, to "drop out of this culture, and find places . . . where we can live godly, righteous, and sober lives." ${ }^{2}$ Not coincidentally, these families, and many others like them, are also making the loudest demands for public subsidies or vouchers that will finance home-schooling as well as private, parochial school tuition for families that seek to remove their children from the public school system. It must be worth at least thinking about the carte blanche we give the privatized family to refuse to teach "our" future citizens public norms of tolerance, equality,

47. See Joseph, supra note 25 , at 29-38.

48. Francine Blau, Lawrence Kahn, and Jane Waldfogel have studied the economic and social structures that incentivize or discourage young women's decisions regarding when and whether to marry, concluding that labor market opportunities and education have significant effects upon these choices. See Francine D. Blau et al., Understanding Young Women's Marriage Decisions: The Role of Labor and Marriage Market Conditions, 53 Indus. \& Lab. Rel. Rev. 624, 645 (2000).

49. See, e.g., Mary Becker, Patriarchy and Inequality: Towards a Substantive Feminism, 1999 U. Chi. Legal F. 21, 73 ("Children are a public good benefiting the entire community: we all benefit from having younger generations of workers, particularly as we age."); Nancy Folbre, Children As Public Goods, Am. Econ. Rev., May 1994, at 86, 86 ("[A]s children become increasingly public goods, parenting becomes an increasingly public service.”).

50. By contrast, some American Indian tribes treat children as belonging to more than just their parents. See Barbara Ann Atwood, Identity and Assimilation: Changing Definitions of Tribal Power Over Children, 83 Minn. L. Rev. 927, 963 n.152 (1999); see also Nancy D. Polikoff, This Child Does Have Two Mothers: Redefining Parenthood to Meet the Needs of Children in Lesbian-Mother and Other Nontraditional Families, 78 Geo. L.J. 459, 474 (1990) (describing collective approaches to parenting). 36 .

51. Margaret Talbot, A Mighty Fortress, N.Y. Times, Feb. 27, 2000, (Magazine), at 34,

52. A Moral Minority? An Open Letter to Conservatives from Paul Weyrich (Feb. 16, 1999), at http://freecongress.org/fcf/specials/weyrichopenltr.htm (on file with the Columbia Law Review). 
and humanity-or worse. ${ }^{53}$ The freedom to indulge such non-public, if not anti-public, preferences in the raising of children can be quite alarming-especially when the public is called upon to finance the raising of these future christian soldiers. ${ }^{54}$ We have delegated to private parties the task of producing and raising the next generation, and we have done so in the absence of any public accountability for what kinds of people this public service produces.

What also strikes me as worthy of examination is the degree to which parenting is described as productive social activity while, in many regards, parenting has become as much or more about consumption than production. Sylvia Ann Hewlett, the founder of the National Parenting Association, mused in a recent op-ed piece in the New York Times about how the public fails to recognize the financial sacrifices that mothers make to raise children. ${ }^{55}$ What with "therapy, summer camp, computer equipment and so on," ${ }^{56}$ kids are just darn expensive, she argued. The "and so on" explicitly includes a "three-bedroom home" in her calculus, but surely implicitly entails Pokémon accessories, My Little Pony dolls, Barbies, fancy sneakers, and other expensive articles of consumption that are aggressively marketed to children these days. While I don't think that children of any economic class should be deprived of the toys and other items that bring joy into their lives, I am concerned about the bourgeois framing of an issue that gives the larger public the tab for the marketinginduced "needs" of children. And all in the name of "society-preserving work." That children want things, or their parents wish to provide them to their children, is an insufficient justification for shifting the costs of those needs to the public. In other words, the framing of needs in the language of rights is always problematic, but particularly so where needs, such as those Hewlett asserts, are invoked so uncritically.

Finally, I have one last concern about the "we must reproduce the species" response to my invitation to legal feminists to critically examine repronormativity in society. Policies favoring reproduction are often justified by the need to create another generation of workers who will sup-

53. See id. ("What I mean by separation is, for example, what the home-schoolers have done. Faced with public school systems that no longer educate but instead 'condition' students with attitudes demanded by Political Correctness, they have seceded.”).

54. The IRS has recently determined that a christian home-schooling organization qualifies as a nontaxable charity. See IRS Exemption Rulings, 153 Daily Tax Rep. (BNA), Aug. 8, 2000, at K-2 (Section 509 (a) (2) -Classification as Nonprivate Foundation Due to Nature of Support). In May 1999, Senate Finance Committee Chairman William Roth unveiled an education package that included education IRA withdrawals for qualified education expenses associated with primary and secondary private schooling and certain home-schooling. See Bud Newman, Tax Legislation: Roth Unveils Education Tax Break Package; Cost of $\$ 7.6$ Billion over 10 Years is Offset, 95 Daily Tax Rep. (BNA), May 18, 1999, at G-4.

55. See Sylvia Ann Hewlett, Editorial, Have a Child, and Experience the Wage Gap, N.Y. Times, May 16, 2000, at A23.

56. Id. 
port us in our old age. ${ }^{57}$ But these policies cannot be disaggregated from immigration policy. The need to maintain a certain corps of tax-paying workers could be met through manipulation of our immigration laws-as we have done in the past to meet demand in particular sectors of the economy. ${ }^{58}$ With the impending bulge in demand on the social security system precipitated by the retirement of baby boomers, more than a few policymakers have suggested that an increase in legal immigration for higher-skilled workers will replenish the system during a period of excessive demand.

Thus we see a convergence of interests among Silicon Valley executives in need of high-tech labor, immigrant rights groups advocating on behalf of undocumented workers, and those concerned with the financial future of Medicare and Social Security materializing in aggressive lobbying to increase the available workforce. To encourage workers to come to the United States, a recently enacted law increased the number of H1-B visas annually made available to skilled workers. ${ }^{59}$ To further bolster the social security system, a proposed amnesty program legalizes the status of numerous illegal immigrants, a measure that both facilitates more employers paying into the current social security system on behalf of their presently employed workers and creates the sizable workforce necessary to support the financial demands that the impending retirement of the baby-boomers will generate. ${ }^{60}$

57. See, e.g., Jane Rutherford, One Child, One Vote: Proxies for Parents, 82 Minn. L. Rev. 1463, 1518 (1998) (describing children as "society's workers, tax-payers, and leaders" and as "qualified workers who can contribute tax dollars toward tomorrow's needs").

58. Beginning in 1907, the federal government vested decisions with respect to the admission of aliens in the Secretary of Labor. See Act of Feb. 20, 1907, ch. 1134, 34 Stat. 898; see also Michael J. Churgin, Immigration Internal Decisionmaking: A View from History, 78 Tex. L. Rev. 1633, 1635 (2000) (reporting proposed legislation to increase number of visas for skilled foreign workers); Richard Delgado \& Jean Stefancic, California's Racial History and Constitutional Rationales for Race-Conscious Decision Making in Higher Education, 47 UCLA L. Rev. 1521, 1550 (2000) (discussing the manner in which Mexicans were admitted into the U.S. for migrant labor in California during a period of acute labor shortage occasioned by the beginning of World War II); Marjorie Valbrun, Renewed Bids for Visas for High-Tech Workers Reflect the Political Influence of Silicon Valley, Wall St. J., Sept. 15, 1999, at A34 (noting expanded influence of Silicon Valley in 2000 elections); Marjorie Valbrun \& Glenn Burkins, Tight Labor Market Shifts Immigration Debate, Wall St. J., Feb. 10, 2000, at A2 (discussing shortage of skilled workers in high-tech industries and proposed legislation to raise immigration cap).

59. See, e.g., Lizette Alvarez, Congress Approves a Big Increase in Visas for Specialized Workers, N.Y. Times, Oct. 4, 2000, at A1 (describing how "the bill's immediate goal is to help high-tech companies recruit employees").

60. See The Economic Need for Immigration, Fin. Times, July 31, 2000, at 19; Julian Simon, Cato Institute and the National Immigration Forum, Immigration: The Demographic and Economic Facts (July 7, 1998), available at http://www.cato.org/pubs/ policy_report/pr-imintro.html (on file with the Columbia Law Review). However, the economic justification for opening up U.S. borders often takes a rather familiar turn when advocates push for the "right" kind of immigrants-those who speak English, are of a certain education and economic class, and can document that they will not become a public charge. See Jodi Wilgoren, California and the West, Immigrants Are a Boon to 
The preference for natalist over immigration-based solutions to this intergenerational support problem have often taken the form of looselyveiled racism, xenophobia, or decolonization. ${ }^{61}$ In Israel, for instance, the government has long-favored maternal policies that generously subsidize Jewish women's maternity and childcare needs while actively discouraging Palestinian women's reproduction. ${ }^{62}$ Similarly, a government report addressing France's slow population growth suggested that the government allow greater immigration. This solution was dismissed out of hand, as the French regarded their country already too full of foreigners. (Multiculturalism has not been embraced by the majority of the French people as a republican value ${ }^{63}$ ) Unlike the myth of the melting pot in the United States, "immigrants have practically no place in the French national memory." 64 Instead, the government opted for very generous state subsidies to French women upon the birth of their second and third child, accompanied by a tightening up of immigration laws, particularly for Franco-Algerians and others from former French colonies. ${ }^{65}$ In case there was any mistaking the motivation for France's aggressive natalism, socialist President Francois Mitterrand explained that nationalism, not socialism, justified his raising family benefits by twenty-five percent as one of his first acts in office. ${ }^{66}$

Economy, Study Says, L.A. Times, July 7, 1998, at A3 (citing a 1990-1991 study that showed that two-thirds of the women giving birth in public hospitals and one in four federal prisoners were undocumented).

61. See Etienne Balibar, Is There a 'Neo-Racism'?, in Etienne Balibar \& Immanuel Wallerstein, Race, Nation, Class: Ambiguous Identities 17, 21 (Chris Turner trans., Verso ed. 1991) (1988) (conceptualizing "new racism" in France as "the reversal of population movements between the old colonies and the old metropolises"); see also Gérard Noiriel, Difficulties in French Historical Research on Immigration, in Immigrants In Two Democracies: French and American Experience 66, 75 (Donald L. Horowitz \& Gérard Noiriel eds., 1992) (arguing that immigration policy, from as far back as 1789, was motivated by "the preservation of the traditional national character . . . admit[ting] the elements capable of assimilation and exclud[ing] the others .... [T] he leitmotif of French political thought on immigration was that in order to preserve the identity of the French people, a policy of ethnic selection must be applied." (citations omitted)).

62. See, e.g., Mimi Ajzenstadt \& John Gal, Appearances Can Be Deceptive: Gender in the Israeli Welfare State 15-18 (June 5, 2000) (unpublished manuscript, on file with the Columbia Law Review) (describing the "clear-cut desire on the part of Jewish decisionmakers to adopt a pro-natal policy to encourage Jewish, but not Arab, demographic growth in the newly formed state").

63. See, e.g., Alec G. Hargreaves, Immigration, 'Race' and Ethnicity in Contemporary France 176 (1995) (describing the reform of French nationality laws); The Missing Children, Economist, Aug. 3, 1991, at 44 (explaining how the French have come to view cultural differences as a negative rather than a positive feature of society).

64. Noiriel, supra note 61 , at $66,68$.

65. See Hargreaves, supra note 63, at 169-76; Nancy L. Green, Le Melting-Pot: Made in America, Produced in France, 86 J. Am. Hist. 1188, 1197 (1999).

66. William Echikson, A Baby Boom, S'il Vous Plait!, Christian Sci. Monitor, Aug. 24, 1983, at 6. See generally Judy Scales-Trent, African Women in France: Immigration, Family, and Work, 24 Brook. J. Int'l L. 705, 708-11 (1999) (describing the increase in African, particularly African female, immigration into France). 
Unfortunately, U.S. immigration policy cannot boast of an absence of racist underpinnings. Nineteenth-century immigration laws allowed Chinese men to enter the United States only as laborers, denied entry to Chinese women and children, and prohibited the laborers from intermarrying with non-Chinese women. ${ }^{67}$ Such a policy isolated Chinese workers so that they could devote their entire lives to their jobs and prevented an undesirable group from reproducing. ${ }^{68}$ Despite our national mythology of the United States as an ethnic melting pot, throughout the nation's history arguments rooted in eugenics and other notions of racial inferiority have been invoked in order to limit immigration and maintain a particular conception of U.S. national identity. ${ }^{69}$

I raise these questions regarding the erasure of the normativity of reproduction with a keen eye to the degree to which the paradigmatic case in each of my examples is a white, middle-class woman. Women of color and low-income women have struggled against overwhelming disincentives to reproduction, ${ }^{70}$ including the forced sterilization of African American, Puerto Rican, and American Indian women, ${ }^{71}$ and the removal of children of color from their birth parents in order to place them in white families. ${ }^{72}$ Our national preference for a natalist solution to preserve society assumes that the production of reproduction take place in white, monied wombs. Similarly, my critique of the privatized family has purchase largely, again, for white, middle-class families. People of color and low-income people have always been vulnerable to intrusive intervention by the state into their family lives. ${ }^{73}$ The questions I raise must be asked with these contexts in mind.

This is not to say that the concerns I suggest here have no relevance to women of color and other women whose reproduction has been struc-

67. Chinese Exclusion Act, ch. 126, 22 Stat. 58, 59 (1882) (repealed 1943).

68. See, e.g., Bill Ong Hing, Making and Remaking Asian America Through Immigration Policy, 1850-1990, at 45-46 (1993) (amply documenting the manner in which U.S. immigration laws were explicitly designed to shape, limit, and manipulate Chinese American, Korean American, and Japanese American identity).

69. See Desmond King, Making Americans: Immigration, Race, and the Origins of the Diverse Democracy 166-95 (2000).

70. See, e.g., Dorothy Roberts, Killing the Black Body: Race, Reproduction and the Meaning of Liberty 23 (1997) ("[Slavery] marked Black women from the beginning as objects whose decisions about reproduction should be subject to social regulation rather than to their own will.").

71. See generally Nancy Ehrenreich, The Colonization of the Womb, 43 Duke L.J. 492, 515 (1993) (detailing the involuntary sterilization of women of color through the 1970 s who were sterilized because they were believed to be "sexually promiscuous and either too irresponsible or too ignorant to use birth control"); Iris Lopez, Agency and Constraint: Sterilization and Reproductive Freedom Among Puerto Rican Women in New York City, 22 Urb. Anthropology \& Stud. Cultural Sys. \& World Econ. Dev. 299, 301-03 (1993) (reviewing incidence of sterilization abuse among Puerto Rican women in New York City).

72. See, e.g., Linda Gordon, The Great Arizona Orphan Abduction 309 (1999).

73. See, e.g., Naomi R. Cahn, Models of Family Privacy, 67 Geo. Wash. L. Rev. 1225, 1243 (1999). 
turally discouraged, if not prohibited. I hope these remarks will at least problematize arguments made on behalf of reproductively disfavored women in which equality and fairness are figured as the restoration of the repronormative privileges enjoyed by women who are not subject to race and class bias-their "unproblematic" behavior is the baseline against which we measure the extent of the bias suffered by women of color and lesbians, for instance. We should be cautious about developing strategies in which assimilation to a white, middle-class hetero/repro norm stands for the absence of coercion, and the restoration of a non-biased natural set of choices.

Surely public and private forces that discourage or stigmatize women of color's reproductive behavior are worthy of strong opprobrium. The data documenting fertility patterns of women in the United States, however, raises interesting questions regarding the presumed baselines that distinguish coerced from freely-chosen reproduction. Notwithstanding structural disincentives to reproduce, women of color are more likely than white women to have children during their lifetime. For instance, $85.5 \%$ of Hispanic/Latina women bear at least one child by the age of 44, as compared with $83 \%$ of African American and Asian American women, and $80.5 \%$ of white, non-Hispanic women. ${ }^{74}$ So too, fertility operates in inverse proportion to income and education. ${ }^{75}$ This data demonstrates durable "preferences" to reproduce among women of color, women earning lower incomes, and less-educated women, but it tells us nothing about the nature of those preferences. These numbers might suggest intracommunity critical, normative discussions regarding the primacy placed upon reproduction. The unstated premise of much of the literature critiquing policies and practices that discourage women of color's fertility is the belief that more women would be reproducing in the absence of these structural disincentives, presumably restoring fertility for Hispanic/Latina women to rates in excess of $90 \%$. Might there be any grounds upon which virtually universal motherhood by Latinas would garner critical attention from critical race feminists? According to what theory of wellbeing, equality, community, and flourishing would a cultural justification or explanation for women of color's overwhelming reproduction be legitimate? Revealing the genealogy of a community norm that privileges large families is surely an important project, but that genealogy does not, standing alone, resolve the question of whether the community norm is one worthy of preserving prospectively. To call it cultural should begin, not end, our critical attention to this issue.

Another way to cast this concern is to ask: What social practices are in need of explanation? Typically, only the deviant, perverse, disfavored, or odd. You do not see biologists plumbing the human genome in search of the "straight gene," nor do we worry that heterosexual kindergarten

74. Bachu \& O'Connell, supra note 11, at 2 tbl.A.

75. Id. at 4 tbl.C. 
teachers will make little kids straight. ${ }^{76}$ The normativity of white, straight middle-class women's repronormative behavior serves to set-off the lesbian/Black/HIV-positive/infertile/disabled woman's predicament as a marked deviation from the natural order.

It is a common feminist practice to rake a gender-based dragnet over a problem and see what it turns up (glass ceilings, sexual harassment, sex segregation at work, disproportionate amount of caretaking/domestic work done by women at home). But it is also important, from time to time, to take an interest in what it does not pick up (most women are mothers, for instance), and ask why. When we peel away the artifice of the naturalness of the unmarked category, sometimes we find a pay-off to some or a price paid by others. These payments and prices may demand a gender-based analysis-at least in part. My point here is to suggest that legal feminism may benefit from exposing all women's reproduction to this sort of scrutiny.

For these reasons, I hope legal feminists might consider the ways in which repronormative forces affect women's child-bearing and raising "choices," just as (hetero)sexuality has come to be understood as both compulsory and ineluctably the product of heteronormative forces. In understanding this project, feminists should not abandon a concern for the role of reproduction and mothering in women's lives. Instead we could stand to pay closer attention to the taken-for-grantedness of motherhood in feminist legal theory. What is our stake in treating motherhood as a social position and a set of both expectations and entitlements not worthy of the level of interrogation we have visited on other fundamental aspects of women's lives? Too few of us have taken this insight as seriously as I believe Fineman intended it and challenged the baseline that accepts motherhood as an inevitability in women's lives. What are we missing by failing to do so?

\section{Getting Stuck In "No"}

Implicitly installing Lysistrada as the patron saint of feminism, for many feminist legal theorists, saying no to sex has been understood as one of the principal ways of saying yes to power. ${ }^{.7}$ No to incest, no to

76. For a recent refreshing counterexample, see Gay Teacher's Disclosure Spurs a Debate, N.Y. Times, June 11, 2000, at 36 (In response to parental uproar at a first-grade teacher revealing to his students that his male partner would be "someone you love the way your mom and dad love each other," the school superintendent responded: "Had the teacher at that point said, 'I'm married and have two kids,' no one would have blinked an eye. . . . There should not be a double standard for heterosexual and homosexual teachers.").

77. The parallel of this strategy to that of Foucault is worth noting: "We must not think that by saying yes to sex, one says no to power." 1 Michel Foucault, The History Of Sexuality 157 (Robert Hurley trans., 1978). Part of Foucault's project in the first volume of History of Sexuality was to critique a conception of sex as a natural drive that stands prior to and outside of relations of power that regulate sexual behavior through organized mechanisms of sexuality. My project in this Essay is to challenge feminist legal theory that 
rape, no to sexual harassment-the link between sex and women's oppression has been one of the fundamental insights of second-wave feminism. ${ }^{78}$ Thanks in no small part to the work of Catharine MacKinnon, ${ }^{79}$ legal feminism can pride itself in having developed a comprehensive analysis of the ways in which male domination of women is achieved by sexual means. ${ }^{80}$ MacKinnon's dominance in legal feminism can be attributed, in large measure, to the degree to which her description of women's oppression intuitively resonates with the experiences of many women.

Because there is much about which Mackinnon is right, she cannot be dismissed out of hand. However, the rightness of her project and the degree to which she overstates her prescription leaves legal feminism in an uncomfortable bind: "To the extent that MacKinnon over determines male sexuality as violence, she under determines female sexuality as the null set," 81 or worse, a terrain fully colonized by male power: "Sex feeling good may mean that one is enjoying one's subordination; it would not be the first time." 82 For MacKinnon, all gender is always already about sexuality, and all sexuality is always already about gender. And both gender and sexuality are entirely about women's subordination to men. ${ }^{83}$ Thus, "no" is the only viable feminist answer to any sexual question.

1) neglects any positive theory of sexuality, 2) overdetermines all sexuality as always already polluted by sexist, male power and therefore toxic to women, or 3) posits a positive conception of sexuality that is the opposite of power.

78. See, e.g., Kathleen Barry, Female Sexual Slavery 194 (1979) ("Sex-is-power is the foundation of patriarchy ... . Institutionalized sexism and misogyny-from discrimination in employment, to exploitation through the welfare system, to dehumanization in pornography-stem from the primary sexual domination of women in one-to-one situations.").

79. E.g., Catharine A. MacKinnon, Feminism Unmodified (1987) [hereinafter MacKinnon, Feminism Unmodified]; Catharine A. MacKinnon, Toward a Feminist Theory of the State (1989) [hereinafter MacKinnon, Toward a Feminist Theory of the State].

80. MacKinnon writes:

Gender socialization is the process through which women come to identify themselves as sexual beings, as beings that exist for men . . . According to this revision, one "becomes a woman"-acquires and identifies with the status of female-not so much through physical maturation or inculcation into appropriate role behavior as through the experience of sexuality .... Women and men are divided by gender, made into the sexes as we know them, by the social requirements of heterosexuality, which institutionalizes male sexual dominance and female sexual submission. If this is true, sexuality is the linchpin of gender inequality.

Catharine A. MacKinnon, Feminism, Marxism, Method, and the State: An Agenda for Theory, 7 Signs 515, 531-33 (1982).

81. Katherine M. Franke, What's Wrong With Sexual Harassment?, 49 Stan. L. Rev. 691, 741 (1997).

82. MacKinnon, Feminism Unmodified, supra note 79, at 218.

83. According to Mackinnon:

[A] theory of sexuality becomes feminist to the extent it treats sexuality as a construct of male power-defined by men, forced on women, and constitutive in the meaning of gender. Such an approach centers feminism on the perspective 
Of course, not all legal feminists have signed up for Mackinnon's project; indeed she has as many critics as she has fans. Nevertheless, even among MacKinnon's greatest critics, the objects of scrutiny in the legal feminist landscape by and large remain those brought into view by MacKinnon's frame. In this domain of legal feminism, sexuality is accounted for not as reproduction and dependency, but as danger. Sexuality is something that threatens from without. It is an exogenous colonizing technology of our (women's) oppression, and is always to be examined with a "feminist eye" to the special injury that sexual violence inflicts on women. Thus, within much of legal feminism, when an objectionable practice takes on a sexual character, it has achieved its most injurious form. Assault is bad; rape is much worse. Workplace harassment is bad; workplace sexual harassment is much worse ${ }^{84}$ Emotional betrayal by a spouse is bad; adultery is much worse. Exploitative working conditions are bad; exploitative sex work is much worse. ${ }^{85}$

Just as the specter of a domain of sexuality that is the excess over bare procreation is erased by many legal feminists who theorize sex as dependency, here we see any excess beyond sexual danger equally erased by legal feminists who construct sex as something that is done to, not by, women. On that ground, we witness the most aggressive calls from feminists for the legal regulation of rogue sexuality, such as pornography, prostitution, infidelity, sexual violence, and sexual predation. Might there be reason for caution in the feminist impulse to exercise juridical control over this excess?

While I might agree that some of this conduct is unquestionably worthy of legal regulation and public condemnation, the feminist call for greater legal sanctions for sexual violence risks playing into the hands of those who regard human sexuality as something to be indulged in only for the purposes of reproduction. ${ }^{86}$ The failure of legal feminists to articulate and press a viable positive domain of non-reproductive sexuality has left such a domain overdetermined as either lesbian territory or the site of surplus male sexuality that is in need of taming, if not excising alto-

of the subordination of women to men as it identifies sex, that is, the sexuality of dominance and submission, as crucial, as fundamental, as on some level definitive, in that process.

Catharine A. MacKinnon, Pleasure under Patriarchy, in Theories of Human Sexuality 67-68 (James H. Geer \& William T. O’Donohue eds., 1987).

84. Vicki Schultz has described this impulse in sexual harassment jurisprudence. See, e.g., Vicki Schultz, Reconceptualizing Sexual Harassment, 107 Yale L.J. 1683, 1685-86 (1998) (describing how the law has come to privilege only sex-based harassment that is sexual in nature).

85. See generally Beverly Balos \& Mary Louise Fellows, A Matter of Prostitution: Becoming Respectable, 74 N.Y.U. L. Rev. 1220, 1303 (1999) (calling for legal reform to "undermine the degeneracy/respectability dichotomy that prostitution embodies").

86. The unfortunate congruence of feminist and radical right campaigns for the regulation of pornography is the best example of this potentiality. 
gether, through juridical means. ${ }^{87}$ The overwhelming attention we have devoted to prohibitions against bad or dangerous sex has obscured, if not eliminated, a category of desires and pleasures in which women might actually want to indulge.

Another aspect of this dynamic is revealed in the priority given to arguments marshaled against certain forms of sexual violence against women. Rarely is the diminishment or marginalization of women's sexual pleasure invoked as a reason, albeit one among others, to oppose particularly odious social practices. Limitations on access to sexual education in schools, as well as an absence of affordable contraception and abortion, are targets of feminist criticism for a number of reasons. Yet, by and large, the basis of the legal feminist demand for greater reproductive resources has been grounded in the avoidance of dependency, ${ }^{88}$ or the importance of women's autonomy or liberty. Indeed, some legal feminists have framed the abortion issue as one that fundamentally involves enabling men's sexual pleasure on the one hand, and women's exploitation on the other. ${ }^{89}$ Women's right to enjoy their own body is entirely absent

87. An ironic implication of this tendency lies where legislatures have enacted laws to address various types of male sexual transgression, but have done so in gender neutral terms, thus exposing women to regulation by these same laws in equal degree. The legal regulation of pornography, adultery, and domestic violence, for instance, has resulted in the seizure of feminist and lesbian writings, see, e.g., Nadine Strossen, A Feminist Critique of "The" Feminist Critique of Pornography, 79 Va. L. Rev. 1099, 1145-47 (1993) (describing seizure of lesbian magazines and books under Canadian anti-pornography law); enforcement of adultery laws against women, see, e.g., Bonura v. Bonura, 505 So. $2 \mathrm{~d}$ 143, 145 (La. Ct. App. 1987) (granting divorce in favor of husband on grounds of wife's adultery); Zeringue v. Zeringue, 479 So. 2d 443, 446 (La. Ct. App. 1985) (upholding mutual fault divorce based on adultery by both parties); Armistead v. Armistead, No. 061497-3, 1998 WL 37320, at*2-*3 (Va. Ct. App. Feb. 3, 1998) (confirming that adultery by wife is grounds for divorce in husband's favor); Peyton v. Countryside Orthopaedics, P.C., No. 18157, 1999 WL 1417214, at *4 (Va. Cir. Ct. Oct. 8, 1999) (wife's adultery considered important if contributing to divorce); and a steep rise in arrests of women pursuant to mandatory arrest policies in domestic violence situations, see Linda G. Mills, Killing Her Softly: Intimate Abuse and the Violence of State Intervention, 113 Harv. L. Rev. 550, 588 n.190 (1999).

88. See, e.g., Robin West, Caring for Justice 141-42 (1997) [hereinafter West, Caring for Justice]; Robin West, Integrity and Universality: A Comment on Ronald Dworkin's Freedom's Law, 65 Fordham L. Rev. 1313, 1325 (1997) ("What Griswold and Eisenstadt protected for both married and unmarried individuals was the freedom to engage in heterosexual intercourse without fear of familial and reproductive consequences.").

89. This has been, in essence, Catharine MacKinnon's approach to the issue. See, e.g., Catharine A. MacKinnon, Reflections on Sex Equality Under Law, 100 Yale L.J. 1281, 1300 (1991) ("Women can have abortions so men can have sex."). Discussions with Kendall Thomas brought this angle to my attention. Opposition to female genital cutting is another excellent example of the sublimation of women's pleasure in the struggle to eliminate sexist practices. Those who advocate for the elimination of these cuttings do so on the grounds that these practices expose women to infection, are extremely painful, and are likely to produce infertility or incontinence. The reduction, if not elimination, of clitoral sexual pleasure is mentioned belatedly, if at all, by many of the activists who oppose these practices. The effect that genital cuttings might have on a girl's capacity for sexual pleasure was not once invoked as among the justifications for federal legislation 
in these feminist legal arguments. It has been the gay and queer legal theorists who see these issues as about a "right to sex." 90

I wonder if an intergenerational moment might have arrived when we would want to de-sacrilize the sex-danger alchemy within feminist legal theory-not to ignore the significance of sexual violence for women, but instead to de-essentialize sex's a priori status as a site of danger for women and one best cleansed of such danger. An example may best illustrate the point. Some of us who teach sexual harassment law have begun using a heuristic that excavates an interesting generational shift. I now ask my students which practice they would find most humiliating, objecti-

condemning so-called "female genital mutilation." See, e.g., H.R. Rep. 103-501, at 10 (1994). The findings state that complications from FGM are common and include immediate shock, bleeding, infection, and death as well as delayed medical problems such as scarring, menstrual pain and blockage, pelvic and urinary tract infections, severe injury and pain during intercourse, infertility, and difficulty with labor and delivery. There also may be psychological complications since these painful rituals can be a source of extreme emotional trauma.

Id. See also Introduction of Legislation to Prevent Female Genital Mutilation and the Dangers of the National Security Revitalization Act, 141 Cong. Rec. H1695 (daily ed. Feb. 14, 1995) (statement of Rep. Schroeder) ("FGM causes serious health problemsbleeding, chronic urinary tract and pelvic infections, build-up of scar tissue, and infertility. Women who have been genitally mutilated suffer severe trauma, painful intercourse, higher risk of AIDS, and childbirth complications.”). Ali Miller and Carole Vance have convinced me that Representative Schroeder and other Western or United Nations feminists have downplayed or eliminated the pleasure argument from their advocacy against female genital surgeries as a strategic matter. While this judgment may make sense on real politik grounds, it does have the effect of perpetuating the erasure of women's sexual pleasure as a significant human rights injury. Indeed, women do not have a human right to the sexual enjoyment of their bodies, but only a right to freedom from infection and pain. See Report of the World Conference of the U.N. Decade for Women: Equality, Development and Peace, Copenhagen, July 14-30, 1980, at 34, U.N. Doc. A/CONF.94/35 (1980). Radhika Coomaraswamy, the United Nations Special Rapporteur on Violence Against Women, has framed women's sexual rights as fundamentally reproductive in nature: "the issue of [women's] sexual rights ... refers generally to a woman's control over her sexuality and her access to primary and secondary health care and reproductive technologies." Radhika Coomaraswamy, Reinventing International Law: Women's Rights as Human Rights in the International Community, Edward A. Smith Lecture at Harvard Law School (Mar. 12, 1996), available at http://www.law.harvard.edu/programs/HRP/ Publications/radhika.html (on file with the Columbia Law Review). Any excess over mere reproduction is framed as an issue of concern to "the gay movement." Id. While Coomaraswamy eloquently makes the case that female genital cutting is a violation of women's human rights, she fails to regard the human rights issue raised by these practices as relating to a limitation on women's sexual pleasure.

90. See David B. Cruz, "The Sexual Freedom Cases"? Contraception, Abortion, Abstinence, and the Constitution, 35 Harv. C.R.-C.L. L. Rev. 299, 300-03 (2000); Richard D. Mohr, Mr. Justice Douglas at Sodom: Gays and Privacy, 18 Colum. Hum. Rts. L. Rev. 43, 83 (1986) ("[T]hough the Court has failed to acknowledge the logical conclusion to its privacy decisions, [the Court] protect[s] the right to have sex.”). Sylvia Law would be an exception to this more general rule in recognizing and arguing for a right to sex on feminist grounds. See, e.g., Sylvia A. Law, Homosexuality and the Social Meaning of Gender, 1988 Wis. L. Rev. 187, 225 ("People have a strong affirmative interest in sexual expression and relationships."). 
fying, or objectionable: having a male boss ask you, out of nowhere, to (i) kiss him, (ii) babysit for his kids, or (iii) be responsible for serving coffee at staff meetings. Few of my female students select the kiss as the most objectionable encounter. When we discuss their reasons for their selections, ${ }^{91}$ I cannot easily write off their failure to get the "right feminist answer" to an impoverished feminist education or false consciousness. Rather, sex seems to have become a less "dense transfer point for relations of [gender-based] power" 92 for some women a generation younger than my feminist peers and I. This is not to say that sex no longer plays a role in gender-based hierarchies, but rather, that we might want to reassess the synergistic danger it presents today as compared with the period in which we first formulated these analyses twenty years ago. Such a generational shift highlights the fact that a feminist approach to sex and sexuality must still simultaneously address the reduction of dangers we face, the burdens of dependency, and the possibilities for women's experiences of pleasure.

Surely legal feminists must remain committed to the idea that "sexuality [is] not an unchanging biological reality or a universal, natural force, but [is], rather, a product of political, social, economic, and cultural processes." ${ }^{93}$ In other words, sexuality has a history. My concern is that current feminist legal theory at times gives way to an impulse to dehistoricize sexuality when we suture women's bodies to motherhood and the inevitability of violence.

\section{What Have We Done?}

In 1984, Gayle Rubin mused that feminism was best equipped to analyze and address gender-based subordination, and that a different discourse was needed to adequately analyze sexuality. ${ }^{94}$ From this observation, many believe, ${ }^{95}$ lesbian and gay, and then queer, theory was born. ${ }^{96}$ For example, the introduction to The Lesbian and Gay Studies Reader, pub-

91. Most students rate babysitting as by far the most objectionable, responding to the greater offensiveness of maternal stereotyping over sex.

92. Foucault, supra note 77, at 103.

93. Kathy Peiss \& Christina Simmons, Passion and Power: An Introduction, in Passion and Power 3, 3 (Kathy Peiss \& Christina Simmons eds., 1989).

94. See Gayle Rubin, Thinking Sex: Notes for a Radical Theory of the Politics of Sexuality, in Pleasure and Danger 267, 307 (Carole S. Vance ed., 1984) ("Feminism is the theory of gender oppression. To automatically assume that this makes it the theory of sexual oppression is to fail to distinguish between gender, on the one hand, and erotic desire, on the other.").

95. Ironically, Rubin is not among those who hold this belief. See Interview, Gayle Rubin with Judith Butler, Sexual Traffic, in Feminism Meets Queer Theory 68, 73 (Elizabeth Weed \& Naomi Schor eds., 1997).

96. Rubin's "Thinking Sex" is the first essay in The Lesbian and Gay Studies Reader (Henry Abelove et al. eds., 1993). Eve Sedgwick's Epistemology of the Closet is widely regarded as one of queer theory's early canonical texts. Here Sedgwick argued that the question of gender and the question of sexuality are "not the same question, that in twentieth-century Western culture gender and sexuality represent two analytic axes that 
lished some ten years later, claimed that "[1] esbian/gay studies does for sex and sexuality approximately what women's studies does for gender." 97 Some theorists, both feminist and queer alike, have understood the parallel evolution of feminist and queer theory over the last decade to be grounded in the artifice that "the kind of sex that one is and the kind of sex that one does belong to two separate kinds of analysis." 98

But surely it is a mistake to draw such a rigid distinction between acts and identities, between who we want to be and whom we want to be with, and between sex as adjective (that thing we are) and sex as verb (that thing we do). To set up the analyses of gender and sexuality as separate critical enterprises is to misread Rubin. Her point was not that issues of sex and sexuality should be fully disaggregated from feminism, but rather that she "wanted to be able to think about oppression based on sexual conduct or illicit desire that was distinct from gender oppression (although . . . not necessarily unrelated or in opposition to it)."99 The wisdom imparted by Rubin in "Thinking Sex," that neither Marxism nor feminism provided all the analytic tools we needed to adequately account for sexuality-based oppression, does not mean that forever more these two critical discourses should have nothing to say about the issue of sexuality. Rather, "feminism's critique of gender hierarchy must be incorporated into a radical theory of sex, and the critique of sexual oppression should enrich feminism." 100

Despite such a challenge, most legal feminists seem to have lost a taste for exploring the intersecting stakes that queer and feminist theory have in fully theorizing questions of sexuality. The dependency or danger stance taken by most legal feminists when it comes to questions of sexuality is a testament to the persuasive power of the structural materialism of theorists such as Catharine Mackinnon and Martha Fineman. Mackinnon has rendered feminism the privileged site for analyzing sexuality understood as danger by subordinating sexual politics to sex-based subordination. ${ }^{101}$ MacKinnon's "nearly metaphysically perfect" portrayal of sexuality as always, already, and absolutely about gender-based subordi-

may productively be imagined as being distinct from one another as, say, gender and class, or class and race." Eve Sedgwick, Epistemology of the Closet 30 (1990).

97. Henry Abelove et al., Introduction to The Lesbian and Gay Studies Reader, supra note 96 , at $\mathrm{xv}, \mathrm{xv}$.

98. Judith Butler, Against Proper Objects, in Feminism Meets Queer Theory, supra note 95 , at 1,7 . Butler, I must note, is not among the theorists who hold this view.

99. Rubin with Butler, supra note 95, at 96 . Rubin says, "I was afraid that if there were no independent analysis of sexual stratification and erotic persecution, well-intentioned feminists and other progressives would support abusive, oppressive, and undeserved witch hunts." Id. at 96-97.

100. Rubin, Thinking Sex, supra note 94, at 309.

101. See, e.g., MacKinnon, Feminism Unmodified, supra note 79, at 218 (arguing that "sexism is basic" and underlies sex); Catharine A. MacKinnon, Sexual Harassment of Working Women: A Case of Sex Discrimination 178 (1979) ("Sexual harassment . . . is socially incarnated in sex roles."); MacKinnon, Toward a Feminist Theory of the State, supra note 79, at 127 ("Male dominance is sexual.").

$\mathbf{R}$

$\mathbf{R}$

$\mathbf{R}$

$\mathbf{R}$

$\mathbf{R}$ 
nation and domination renders Rubin's demand for an analysis of sexuality outside of gender not only irrelevant, but incomprehensible. On the other hand, Martha Fineman has done an outstanding job of decoupling relationships grounded in dependency from those grounded in sexual desire, and in so doing has provoked a radical rethinking of motherhood. ${ }^{102}$ In a sense, by framing the feminist project in gender-based terms, MacKinnon has explicitly ruled in all sexuality as gender-based subordination, while Fineman has implicitly ruled it all out, preferring to set her sights on gender and dependency constructed in asexual terms. But too few of us, as legal feminists, have stepped in to re-theorize the significance for women of non-reproductive intimacy, desire, and eroticism that end up as the detritus of Fineman's work.

Is there sexuality beyond kinship that we could call feminist? If Fineman pries open the possibility of non-reproductive sex or other intimate relationships with someone or someones other than the person or persons with whom one parents, what would be a feminist approach to these erotic/intimate possibilities? What if we went all the way with Fineman's suggestion, and declared women's sexuality to lie only in this non-reproductive excess?103 After all, this is the domain of the female orgasm. We might want to explore, if only provisionally, what we might gain if we disaggregated reproduction from sex, and treated them as two distinct aspects of women's lives, potentially interrelated, but not necessarily so. Perhaps it is time that we dust off our Shulamith Firestone. ${ }^{104}$

What might be the consequences of de-sexualizing kinship relationships, not for kinship, which is Fineman's project, but for sexuality? Do we run any risk of constructing women as de-sexualized dependency workers who spend most of their intimate energies on runny noses and very little on other more, er, adult body functions? Might we not want to explore the necessary connections between the regulation of kinship/ family and the regulation of sexuality? Subsidies for reproduction surely incentivize certain repronormative uses of the body, not to mention marriage, monogamy, and the heterosexual family_all of which are methods

102. See, e.g., Fineman, Neutered Mother, supra note 26, at 8 ("I offer a utopian revisioning of the family-a reconceptualization of family intimacy that redefines the legal core unit away from our current focus on sexual or horizontal intimacy.").

103. Sedgwick seems to lay claim to this excess as the rightful domain of queer theory: "There is a powerful argument to be made that a primary (or the primary) issue in gender differentiation and gender struggle is the question of who is to have control of women's (biologically) distinctive reproductive capability." Sedgwick, supra note 96, at 28; see also Biddy Martin, Sexualities Without Genders and Other Queer Utopias, 24 Diacritics 104, 107 (1994) ("Gender, and the theory of gender offered by feminism, then, are associated [by Sedgwick] with reproduction and with women."). I want to resist a doctrinal boundary dispute in which queer theory picks up where feminism leaves off, and the reproductive or non-reproductive nature of the sexual activity is what separates a queer from a feminist issue.

104. Shulamith Firestone, The Dialectic of Sex: The Case for Feminist Revolution 233-34 (1970) (arguing that the only means to achieve women's liberation is through the technological separation of reproduction from the female body). 
by which our hedonic lives are tied to "proper" kinship formation favored by the state.

In the absence of a robust cultural norm in which women's erotic pleasure can be valorized and celebrated for its own sake, many women feel they are faced with two rather undesirable choices when they consider their own erotic desires separate from reproduction or as something offered in exchange for domestic labor. They risk either being labeled sluts or nymphomaniacs ${ }^{105}$ if they seek out sexual pleasure for its own sake, or they face the dilemma described by Elizabeth Abbott in her new book on the history of celibacy. ${ }^{106}$ She explains her own decision to be celibate:

[C] elibacy has major tangible benefits, namely respite from the time-consuming burdens of housewifery . . . . No longer do I need to plan, shop for, cook, serve, and clean up after a week's meals, or iron the shirts I once foolishly boasted I could do better than the dry cleaner, or answer that infernal question "Honey, where are my socks?"107

Being a de-eroticized mother cannot be the only viable alternative to being a slut or celibate.

Men have almost entirely colonized the domain of sexuality that is the excess over reproduction as for them and about them. Movies, advertising, and fashion are largely projections of male fantasy-what would it mean for women to appropriate some of this cultural excess? Just as we have accepted that sexual orientation is not merely a natural phenomenon, might we also want to explore the degree to which our passions, fantasies, secret and not so secret desires are products of the world we live in? Judith Walkowitz has observed that " $[\mathrm{w}]$ omen ... do not simply experience sexual passion and 'naturally' find the words to express those feelings."108 Rather, those things we experience as our own desires are largely the product of a complex combination of external systems of social forces and internal personalized conventions residing in the unconscious. ${ }^{109}$

Surely legal feminists would want to theorize the sexual nature of human sexuality that is the "excess over or potential difference from the bare choreographies of procreation." 110 Is there a reason why we have neglected to take notice of the fact that women are substantially more likely to be unhappy about their sex lives than are men? Is there something that we, as legal feminists, should be doing to address the fact that

105. See Carol Groneman, Nymphomania: A History 121 (2000).

106. See Elizabeth Abbott, A History of Celibacy 429-30 (2000).

107. Id. at 429.

108. Walkowitz, supra note 6 , at 9 .

109. Teresa de Lauretis has written a lovely essay in which she elaborates a theory of sexuality that draws in equal measure from Foucault's theory of social construction and Freud's notion of the unconscious. See Teresa de Lauretis, The Stubborn Drive, 24 Critical Inquiry 851, 851-63 (1998).

110. Sedgwick, supra note 96 , at 29. 
forty-three percent of women in the United States are suffering from diagnosable sexual dysfunction, symptomized by a lack of interest in sex, inability to achieve orgasm or arousal, and pain or discomfort during sex? ${ }^{111}$

We have done a more than adequate job of theorizing circumstances in which "no" is the right answer to a sexual encounter, but where are we on the conditions under which we would be inclined to say "yes"? What particular contribution can we as legal theorists make to these questions? Why have we done such a meager job of thinking of the "sex issue" in positive rather than negative terms, particularly compared with our sisters in other disciplines?

Many feminist legal strategies presuppose men's sexuality as everdangerous, and situate female sexuality as its opposite-a trap set, in part, by the overwhelming heteronormativity of much of this feminist legal theorizing. Within this normative frame, one's desire runs in the opposite direction of one's identity, and male and female identity are set up in antinomous terms. Men desire women, their opposite, and that desire takes a form that is good for them, and bad for us, empowers them, subordinates us, subjectifies them, objectifies us. Many feminist theorists have taken up the project of using law to tame sexual danger, hoping to leave in their wake a domain of safe sex, of love and intimacy in which danger figures as sex's opposite. ${ }^{112}$

Such a theory of the relationship between gender, sexuality, and subordination provides no satisfactory purchase on the question of women's sexuality, except as to say that it amounts to the projection of violent male desire. This conclusion is manifestly unappealing, for it leaves as its remainder only three ways to affirmatively conceive women's desire once liberated from the objectifying constraints of patriarchy: One, a mere absence or void, best understood as the trauma or injury that male sexuality leaves in its wake. Two, a warm, fuzzy, soft-focused cuddling ${ }^{113}$ not the hot, steamy, edgy stuff that got us into trouble in the first place. Or three, a desire that risks bumping up against danger. Feminist legal theory often dismisses this last option as either false consciousness, or worse, women imitating male sexuality. But to evacuate women's sexuality of any risk of a confrontation with shame, loss of control, or objectification

111. Edward O. Laumann et al., Sexual Dysfunction in the United States: Prevalence and Predictors, 281 JAMA 537, 540 (1999) [hereinafter Laumann et al., Sexual Dysfunction] (finding that sexual dysfunction is more prevalent among women than men, and is associated with age, race, and education).

112. See West, Caring for Justice, supra note 88, at 114-16 (arguing that women's sexual pleasure is necessarily sacrificed in sexual relationships with men because of a fear of violence); Mary Becker, Women, Morality, and Sexual Orientation, 8 UCLA Women's L.J. 165, 191-203 (1998).

113. Michael Warner warns of sexual moralism that "too often paint [s] a sanitized, pastoral picture of sex, as though it were simply joy, light, healing, and oneness with the universe." Michael Warner, The Trouble with Normal: Sex, Politics, and the Ethics of Queer Life 3 (1999). 
strikes me as selling women a sanitized, meager simulacrum of sex not worth getting riled up about in any case.

Desire is not subject to cleaning up, to being purged of its nasty, messy, perilous dimensions, full of contradictions and the complexities of simultaneous longing and denial. It is precisely the proximity to danger, the lure of prohibition, the seamy side of shame that creates the heat that draws us toward our desires, and that makes desire and pleasure so resistant to rational explanation. It is also what makes pleasure, not a contradiction of or haven from danger, but rather a close relation. These aspects of desire have been marginalized, if not vanquished, from feminist legal theorizing about women's sexuality.

It bears noting that a soft-focused portrayal of female sexuality that is set off against the hard-edged conception of male sexuality, as well as the inclination to reduce questions of sexuality to matters of kinship or mothering, mirrors the dominant account of female and male sexuality provided by traditional sexologists that has undergone rigorous critique by feminist and queer sex researchers. ${ }^{114}$ According to Rebecca Young, the view that predominated until less than twenty years ago characterized female sexuality as "romantic, non-genital, passive/responsive, monogamous, and not open to autonomous expression. In this stereotype, the normal woman is so chaste that her arousal can scarcely be termed sexual, but is instead a purely emotional response: 'romantic longing.'"115 The material Young examines reveals "[f] emale sexual desire and expression [is] not so much an end in itself as . . . a means for fulfilling other needs and desires: love and motherhood." 116

It cannot be right that feminists should leave to queer theorists the job of providing an affirmative theory of sex that accepts and accounts for the complex ways in which denial, shame, control, prohibition, objectification, and power enable or capacitate desire and pleasure. Surely a thick conception of gender, one that we would call feminist, should be brought to bear on this project.

On the other hand, perhaps the place we find ourselves in legal feminism reveals something more about our situation within law. Is it possible that the task of theorizing yes is not one easily susceptible to the analytical tools legal theory provides? Or have we, despite our frequent protestation to the contrary, ${ }^{117}$ fallen victim to the myopia of which our discipline

114. For a recent sustained critique, see Rebecca Marie Young, Sexing the Brain: Measurement and Meaning in Biological Research on Human Sexuality 251-99 (2000) (unpublished Ph.D. dissertation, Columbia University) (on file with the Columbia Law Review).

115. Id. at 260.

116. Id. at 253.

117. See, e.g., Susan Bandes, The Negative Constitution: A Critique, 88 Mich. L. Rev. 2271, 2279 (1990); Mary E. Becker, The Politics of Women's Wrongs and the Bill of "Rights": A Bicentennial Perspective, 59 U. Chi. L. Rev. 453, 456 (1992); Patricia J. Williams, Alchemical Notes: Reconstructing Ideals from Deconstructed Rights, 22 Harv. C.R.-C.L. L. Rev. 401, 405 (1987). 
in general suffers: thinking of rights and liberties primarily in negative rather than positive terms? ${ }^{118}$ If this is the cause, at least in part, of legal feminism's failure to take on the simultaneous projects of negative and positive sexual liberty, what would that positive project look like?

Perhaps we face an opportunity to drag the feminist net over particular areas of law and see how a gendered construction of sexuality plays out. Take tort damages, for instance. Men are more than twice as likely to plead sexual dysfunction as a basis for money damages in personal injury claims than are women. ${ }^{119}$ In some cases, courts are more willing to reward the physical disfigurement of women than their loss of sexual pleasure. ${ }^{120}$ The recent study of sexual dysfunction among women found that there are a substantial number of women who have suffered loss of sexual desire and satisfaction as a result of various trauma. ${ }^{121}$ That injury has been rendered invisible in tort law. Particularly given that we are now living in the Viagra years, it would behoove us as legal theorists to pursue strategies that would elevate women's sexual pleasure to the same level as that enjoyed by men. While women's rights advocates fought hard in Congress and in the courts ${ }^{122}$ to have reproduction count as a major life activity in the Americans with Disabilities Act, what are the implications of this statutory preference, and the arguments we have made in its support, for women's non-reproductive sexuality? Women's sexual pleasure is not currently recognized in law as a major life activity.

As cultural practices, our legal practices produce legal and social subjects. We, the feminist legal theorists, must remain attentive to the dangers of pursuing modes of analysis and argument that suffer from a kind of theoretical phototropism that has amply nourished a theory of sexuality as dependency and danger at the expense of a withering positive theory of sexual possibility. Given the well-known dangers that lie in the substantive legal regulation of sexual pleasure, ${ }^{123}$ it may be that the best we can aspire to, as feminist legal theorists, is a set of legal analyses, frames, and supports that erect the enabling conditions for sexual pleasure. If that modest work is the best we can expect from law, that still leaves us much work to be done.

118. See, e.g., Elizabeth Schneider, The Dialectic of Rights and Politics: Perspectives from the Women's Movement, 61 N.Y.U. L. Rev. 589, 590-93 (1986).

119. This observation is based upon my less-than-scientific survey of personal injury actions over the last ten years.

120. See, e.g., Hammer v. Township of Livingston, 723 A.2d 988, 992 (N.J. Super. Ct. App. Div. 1999) (concluding that plaintiff's allegation of loss of regular sexual relations is not a "substantial" loss of a bodily function).

121. See Laumann et al., Sexual Dysfunction, supra note 111, at 537.

122. See, e.g., Bragdon v. Abbott, 524 U.S. 624, 639 (1998) (finding that reproduction qualifies as a major life activity under the ADA).

123. Foucault cautions against involving the law in regulating the domain of the sexual and the erotic. See Michel Foucault, Politics, Philosophy, Culture: Interviews and Other Writings 1977-1984, at 200 (Lawrence D. Kritzman ed. \& Alan Sheridan et al. trans., 1988), discussed in Katherine M. Franke, Putting Sex to Work, 75 Denv. U. L. Rev. 1139, 1142 (1998). 